\title{
Impact of Public Debt, Deficit and Debt Financing on Private Investment in a Large Country: Evidence from the United States
}

\author{
AMIR KIA ${ }^{a}$ \\ Received: 29.05.2020; Revised: 05.11.2020; Accepted: 10.11.2020
}

This paper analyses the direct impact of fiscal variables on private investment. The current literature ignores one or more fiscal variables and, in many cases, the foreign financing of debt. In this paper, an aggregate investment function for an economy in which firms incur adjustment costs in their investment process is developed. The developed model incorporates the direct impact of government expenditure, public debt and investment, deficits and foreign-financed debt on private investment. The model is tested on US data. It is found that public investment does not have any impact on private investment, but government expenditure, deficit, debt and foreign-financed debt crowd out private investment over the long run. However, deficit crowds in the private investment over the short run.

JEL codes: H54, E13, E22

Keywords: Private investment, Public debt, Deficit, Foreign-financed debt, Adjustment cost

\section{Introduction}

The majority of recent studies analyze the impact of fiscal variables, especially public debt, on domestic investment through their impacts on the real interest rate. The overall conclusion of these studies is mixed. For some of them, public debt causes the long-run real interest rate to go up while others find there is no or a very weak impact of the public debt on the real interest rate (e.g, Barth et al., 1991; Elmendorf \& Mankiw, 1999; Gale \& Orszag, 2004; Engen \& Hubbard, 2005; Ardagna et al., 2007; Laubach, 2009; Claeys et al., 2012; Kameda, 2014). If the result of public debt is a higher net return to capital, then it can crowd in private investment. If the result is a reduction in capital tax rates or an increase in productive government investment, then the net return to capital will rise, which leads to higher investment.

However, many studies, (e.g, Leeper et al., 2010; Uhlig, 2010), find that the opposite is true if the fiscal instrument increases the income tax rate. Traum \& Yang (2015) conclude that even when there is a negative relationship between investment and government debt expansions, no systematic reduced-form relationship between debt and real interest rates

a Finance and Economics Department, Utah Valley University, Utah, USA. email: akia@uvu.edu https://orcid.org/0000-0002-6388-1453 
exists. That is why empirical studies focusing on the relationship between interest rates and debt are often inconclusive about the extent of crowding out by government debt. In fact, an indirect test of the impact of debt on private investment through its impact on the real interest rate can be misleading.

As for the direct impact of government debt, debt management, deficit, expenditure and investment on private investment, the literature is relatively very thin. In fact, to the best knowledge of the author, there is no study that simultaneously analyses whether large debt and its management, deficit and government expenditure, as well as public investment, interact with private investment, which also leads to capital accumulation and economic growth (e.g, Aschauer, 1989; Alesina et al., 2002; Link, 2006; Afonso \& St. Aubyn, 2009; Desroches \& Francis, 2010). ${ }^{1}$

Recent studies incorporate fiscal variables in their investment functions, but many ignore government debt or used it in a limited way, (e.g, Ratto et al., 2009; Forni et al., 2009; Cogan et al., 2010; Salotti \& Trecroci, 2016; Blackley, 2014; Traum \& Yang, 2015). In general, the current literature ignores one or more fiscal variables and, in many cases, the foreign financing of the debt. When the deficit/debt is financed domestically, there will be fewer domestic funds available for investment, provided there will not be enough capital inflow to offset it. This results in the rise of interest rate over time and consequently the reduction (crowding out) in the private investment. Therefore, we expect a positive relationship, at least over the long run, between government foreign-financed debt and domestic investment.

To fill the gap in the existing literature, we develop an aggregate investment function for an economy, in which firms incur adjustment costs in their investment process. The model incorporates the direct impact of government expenditure, public debt and investment, deficits and foreign-financed debt on investment. It will be tested on US data.

It is found that public investment does not have any impact on private investment, but government expenditure, deficit, debt and foreign-financed debt crowd out the private investment over the long run, whereas deficit crowds in private investment over the short run. This study also shows that wage rate can increase the level of investment but lowers the ratio of investment and stock of capital in the long run. Furthermore, while a higher real interest rate can lower the level of domestic investment over the long run, it does not have any effect on the ratio of investment to the stock of capital over the short run. It is also found that public investment could increase the level of capital over the long run. The government spending will be increased by a higher interest rate, deficit, foreign-financed debt and public investment over the long run, whereas the reverse is true for the debt-toGDP ratio. Interestingly, it is found that a higher interest rate can lower deficit, but a higher public debt and public investment result in a higher deficit over the long run.

The next section covers the survey of the literature. Section 3 introduces the model. Section 4 is devoted to the description of the data and empirical evidence. The final section provides a summary and conclusions.

\footnotetext{
${ }^{1}$ Note that public investment can also crowd out or in private investment. For example, Keynes mentioned that a regular program of public investment as a way to stimulate private investment is effective, see Blackley (2014) and its references.
} 


\section{Literature Review}

There is no very recent study on the area of this paper. In general, most of the recent studies analyze the impact of fiscal variables, especially public debt, on domestic investment through their impacts on the real interest rate. Some studies, e.g., Barth et al. (1991), Elmendorf \& Mankiw (1999), Gale \& Orszag (2004), Engen \& Hubbard (2005), Ardagna et al. (2007), Laubach (2009) and Kameda (2014) find a positive effect on long-run real interest rate. Some others find there is no or a very weak impact of the public debt on the real interest rate. For example, Claeys et al. (2012) find that the crowding-out effect of public debt on domestic long-term interest rates is small because of financial integration. The lower the market integration is, the higher the impact of public debt on the domestic interest rate will be. Furthermore, Azzimonti et al. (2014) show that governments may increase the levels of their debt when financial markets become more integrated.

In fact, higher public debt can crowd in private investment if it results in a higher net return to capital even when there is a higher real interest rate. For example, if the debt is generated by a reduction in capital tax rates or by an increase in productive government investment, the net return to capital will rise and will lead to higher investment. As it is shown by Leeper et al. (2010) and Uhlig (2010), the opposite is true if the fiscal instrument is to increase the income tax rate. Furthermore, Traum \& Yang (2015) estimate a NewKeynesian dynamic stochastic general equilibrium model using Bayesian methods to evaluate the extent of crowding out by government debt for the US economy. The study concludes that even when a negative relationship between investment and government debt expansions exists, no systematic reduced-form relationship between debt and real interest rates exists. That is the reason why empirical studies focusing on the relationship between interest rates and debt are often inconclusive about the extent of crowding out by government debt. So, an indirect test of the impact of debt on private investment, i.e., through its impact on the real interest rate can be misleading.

As it is mentioned in the introduction, for the direct impact of government debt, debt management, deficit, expenditure and investment on private investment, the literature is relatively very limited. For example, the following studies ignore fiscal variables like the deficit, debt and foreign financing.

Aschauer (1989), using a neoclassical model, finds that, while public investment has a negative impact on private investment, public capital increases the productivity of private capital. The study concludes that the overall effect of a rise in public investment expenditure is likely to raise private investment. Alesina et al. (2002) find a negative effect of public government expenditure on business investment. Link (2006), using an ad-hoc model, finds public expenditure reduces new investment in plant and equipment. Afonso \& St. Aubyn (2009), also using an ad-hoc investment model for 17 developed countries, find the impact of public investment on private investment varies across countries. Desroches \& Francis (2010), using an ad-hoc model, analyze the determinants of global investment and global savings, as well as the world real interest rate. They use data from 35 industrial and emerging economies during the sample period of 1970 to 2004. The results of their empirical work suggest that unexpected temporary shocks to income could lead to significant short-term fluctuations in savings behavior and real interest rates. 
As it is mentioned in the introduction, recent studies incorporate fiscal variables in their investment functions, but many ignore government debt or used it in a limited way, (e.g., Ratto et al., 2009; Forni et al., 2009). Cogan et al. (2010) assumes that the particular path for taxes is determined by a fiscal policy rule which responds to the level of government spending and government debt. They find government spending crowds out private investment. ${ }^{2}$ No formal model is introduced, and no other fiscal variables are considered, except for government expenditure. Salotti \& Trecroci (2016), using an ad-hoc model of investment, find a high-level debt has harmful effects on the dynamics of productivity and investment spending.

Moreover, Blackley (2014), also using an ad-hoc investment model, finds long-run net effects of domestic government purchases do not include direct crowding out with public investment. In fact, public investment contributes to additional private investment, but military investment reduces private investment in the US Other fiscal variables are ignored in this study. Traum \& Yang (2015) find that, except for the government investment shock, the investment response to distortionary fiscal financing is mostly negative. Furthermore, they find that with 5-year delayed financing, crowding out is smaller in the short run and medium run, but it comes at a price of more severe crowding out in the longer run. Delayed financing means higher debt services and hence higher debt accumulation. As a result of delayed financing, since more fiscal adjustments are required later, it is worsening and prolonging the crowding-out effect. Again, other fiscal variables are not included in their analysis. As mentioned in the introduction section of this study, we fill the gap in the literature.

\section{The Model}

There are many models of business fixed investments: (i) The generalized accelerator model, which assumes the capital-output ratio is constant. The net investment is related to the change of outputs, spread over a number of time periods, through a set of distributed lag coefficients. There are many variations of the accelerator model. The most satisfactory version is an adjustment cost approach first introduced by Eisner \& Strotz (1963) in which firms pay a penalty for having capital stock different from the desired level and so incur adjustment costs. (ii) The accelerator-cash flow model adds a profit or cash flow terms to an accelerator investment equation. This is based on the assumption that changes in profits should convey some new information about future profitability and, in an imperfect market, internal funds could be less costly than external financing. (iii) The neoclassical model derives the desired capital stock from the equilibrium condition of profit maximization of a firm under perfect competition. There are many variations of this model. (iv) Finally, Tobin's Q theory, where $\mathrm{Q}$ is the ratio of the market value of assets to replacement costs. If a dollar investment leads to a rise in the market value of the asset by more than one dollar, that investment will take place. In other words, if the market value of a firm exceeds the replacement cost of its assets, it can increase its market value by investing more. Conversely, if the market value of a firm is less than the replacement costs of its assets, it can increase the value of shareholders' equity by reducing its stock of fixed assets.

2 Although out of scope for this paper, recent studies on government expenditure multipliers ignored government debt and its management. For a recent summary, see Ramey (2019). 
Which theory of investment is the most appropriate for the aggregate economy? Empirical verification is required to answer this question. However, Wisley \& Johnson (1985) test different investment theories on quarterly US data and finds no specific answer to the above question. Consequently, any model of the investment may be appropriate for the aggregate economy. The model introduced in this section, hence, has a neoclassical nature where discount rates are subjectively determined.

Consider an economy populated with a single firm, representing a large number of identical firms interacting in a competitive environment. There is only one good that can be used either for consumption or investment. The firm's technology can be represented by a production function of the Cobb-Douglas form. The arguments of the production function are: $L_{t}$ is labor input in efficiency units; $K_{t}$ is the stock of physical capital at the beginning of period $t ; G I_{t}$ is real federal government investment (e.g., government expenditure on structures, equipment, and software such as new highways, schools, and computer) and $N_{t}$ is the labor input in time units where:

$$
L_{t}=N_{t} e^{T_{t}}
$$

where $T$ is the disembodied Harrod-Neutral technological improvement for all $t$. This technology is described by

$$
Q_{t}=A K_{t}^{\alpha_{1}} L_{t}^{\alpha_{2}} G I_{t}^{\alpha_{3}}
$$

where $\alpha$ 's are constant coefficients and $\sum_{i=1}^{3} \alpha_{i}=1 . A$ is positive and constant. The capital stock is assumed to be a quasi-fixed factor and to be fully utilized, i.e., the rate of capital utilization during period $t$ is one. The capital market is assumed to be perfect in the sense that firms can lend and borrow at a given rate of interest as long as the present value of the firm is positive. We also assume that there is no corporate tax, but there is a lump-sum tax.

Production function (2) is used by many authors, (e.g., Gould, 1968; Treadway, 1970) who do not include the government investment as an argument contrarily to Hercowitz (1986) whose empirical result on Canadian data finds a positive and significant coefficient for GI. Other authors reach the same conclusion for different countries, see Barro (1981) for the US, Ahmed (1986) for the U.K. and Abiad et al. (2016), who find public investment raises output both in the short run and long run, using 17 Organization for Economic Co-operation and Development (OECD) economies over the 1985-2013 period. Bernanke (1983) also believes that macro-level factors like government expenditure, etc., are important in micro-economic investment decisions.

Following Lucas (1967), Gould (1968), Treadway (1970), Brechling (1975) and Hercowitz (1986), the evolution of the capital stock overtime is the following.

$$
K_{t+1}=\left(1-\delta_{t}\right) K_{t}+I_{t}
$$

where $0<\delta_{t} \leq 1$ is a rate of depreciation and $I$ is the real firm's gross investment. We will assume the adjustment costs of the firm have the following form:

$$
C_{t}=b_{0}+b_{l} I_{t}^{2}-b_{2} Q_{t}
$$


where $C$ is the firm's real adjustment costs in terms of $Q$, and $b$ 's are constant. ${ }^{3}$ There are many specifications for the adjustment costs. For instance, Lucas (1967) assumes these costs $(C)$ to have $b I^{2} / K$ function, where $I$ is the rate of investment, $K$ is the stock of capital and $b$ is a constant coefficient. Gould (1968) assumes the form of $C_{t}=b_{0}+b_{1} I_{t}^{2}$ for these costs, and Treadway (1970) assumes that $C$ is an element of the production function without any separability assumption. Some authors also introduce linear (rather quadratic) or concave adjustment costs (Söderström, 1976; Brechling, 1975).

Rothschild (1971) shows the significance of choosing different adjustment costs in the firm's decision-making process under static expectations. If adjustment costs are concave or linear, the entire response to a change in market conditions is concentrated in the first period following the change, while the firm's response will be distributed over time for strictly convex adjustment costs, provided it responds at all. Furthermore, as it is mentioned by Scarth (1984), the existence of adjustment costs scales down a one-good model to a twosector model due to the need to distinguish between consumption and investment goods.

To have a stable economy, we then need the consumption good sector to be capitalintensive (Allen, 1967, 234). Thus, $C$ can be, say, $b I^{2} / Q$, where $Q$ is the real output. This specification is associated with a stable economy (Scarth, 1984, 850). ${ }^{4}$ Equation (4) is a semi-linear approximation of the adjustment costs function introduced by Scarth.

Each firm in the economy maximizes the present value of its net cash flow $(R)$, which is defined by receipts and payments caused by real production activities. Let us drop purely financial flows arising from borrowing and debt repayment since they cancel out each other (Brechling, 1975, footnote 5). Hence, we can write

$$
R_{t}=Q_{t}-W_{t} N_{t}-q_{t}\left[\dot{0}_{t}+\delta_{t} K_{t}\right]-b_{0}-b_{1} I_{t}^{2}+b_{2} Q_{t},
$$

where $q$ is the real price of capital in terms of $Q$ at time $t, W_{t}$ is the real wage rate at time $t$ and $\stackrel{0}{K_{t}}=K_{t+1}-K_{t}$, or in a continuous manner $\stackrel{0}{K_{t}}=d K / d t .{ }^{5}$ A rationally managed firm in our model maximizes the present value of all future net cash flows by choosing $N_{t}$ and $K_{t}$, i.e.,

$$
\operatorname{Max} V=\int_{0}^{\infty}\left[Q_{t}-W_{t} N_{t}-q_{t}\left[\stackrel{0}{K_{t}}+\delta_{t} K_{t}\right]-b_{0}-b_{1} I_{t}^{2}+b_{2} Q t\right] e^{-s_{t}} d t,
$$

where $s_{t}$ is the firm's subjective real discount rate at time zero for cash flows to be received at time $t$ and $s_{t}=\int_{0}^{\infty} r_{v} d v$, and $r_{v}$ is the instantaneous subjective real discount rate prevailing at time $v .^{6}$

Note that our discount rate is purely subjective and is a function of the real interest rate as well as other variables. The specification of this rate will be given later in the paper.

\footnotetext{
3 Adjustment costs are both internal and external to a firm. Internal costs include installation, training and hiring costs, while external costs are due to market forces, e.g., when the unit price of capital (supply price) increases by the amount of the purchase (the case of monopsony).

${ }^{4}$ Scarth also shows other properties of this specification.

${ }^{5}$ Note that with the adjustment costs, which constrain the rate of investment, the real return on equity holding may deviate from the marginal product of physical capital leading to appropriate movements in the price of equity claims on that capital.

${ }^{6}$ We are assuming that the firm has perfect knowledge of future net flows.
} 
The Euler differential equations that must be satisfied by the functions which maximize the integral (6) are:

$$
\begin{gathered}
\partial V_{t} / \partial N_{t}=e^{-s t}\left[\alpha_{2} Q_{t}+\alpha_{2} b_{2} Q_{t}-W_{t} N_{t}\right]=0 \\
\partial V_{t} / \partial K_{t}-\partial\left(\partial V_{t} / \partial \stackrel{0}{K_{t}}\right) / \partial t=e^{-s t}\left[\alpha_{1} Q_{t}\left(1+b_{2}\right)-q_{t} K_{t}\left(\delta_{t} r_{t}\right)\right. \\
\left.+K_{t} \stackrel{0}{q}_{t}-2 b_{1} I_{t} K_{t}\left(\delta_{t}+r_{t}\right)+2 b_{1} \stackrel{0 .}{I}_{t}\right]=0
\end{gathered}
$$

Equation (7-1) is the familiar marginal productivity condition under adjustment costs. Here demand for labor is

$$
\left.N_{t}=\alpha_{2}\left[\left(1+b_{2}\right) Q_{t}\right)\right] / W_{t} .
$$

Demand for labor will increase by output and will fall by the real wage rate. Using system 7 and production function (2), we will have

$$
\stackrel{0 .}{I_{t}}=\left(\delta_{t}+r_{t}\right) I_{t}-f_{t},
$$

where $f_{t}=\left(1 / 2 b_{1}\right)\left\{-\left(\delta_{t}+r_{t}\right) q_{t}+\stackrel{0}{q}_{t}+\left[\left(1+b_{2}\right) \alpha_{1} K_{t}^{\frac{-\alpha_{3}}{1-\alpha_{2}}} \Omega_{t}\right]\right\}$, and

$\Omega_{t}=A^{\frac{1}{1-\alpha_{2}}}\left[\alpha_{2}\left(1+b_{2}\right) W^{-1}\right]^{\alpha_{2} /\left(1-\alpha_{2}\right)} G I_{t}^{\alpha_{3} /\left(1-\alpha_{2}\right)} e^{\alpha_{2} T_{t} /\left(1-\alpha_{2}\right)}$

Let us assume that time paths of the economic variables in $f_{t}$ are such that this function is continuous, positive, and bounded. Hence, the general solution to (9) will be:

$$
I_{t}=-I_{0} \exp \left\{\int_{t}^{t_{0}}\left(\delta_{t}+r_{v}\right) d v\right\}+\int_{t}^{t_{0}} f_{s} \exp \left\{\int_{s}^{t}\left(\delta_{t}+r_{s}\right) d_{s}\right\} d_{s},
$$

where the solution passes through $t_{0}$ and $I_{0}$. Let us follow Gould (1968) and assume an infinite horizon. Then the specific solution will be:

$$
I_{t}=\int_{t}^{\infty} f_{s} \exp \left\{-\int_{t}^{s}\left(\delta_{t}+r_{v}\right) d_{v}\right\} d_{s} \cdot^{7}
$$

The rate of investment will depend on the entire path of prices, including the price of capital, wages, etc. Gould (1968) shows that the results obtained by assuming constant values for prices, wages, and firm's subjective interest rates over time extend in a natural way to timedependent prices. Such conclusion is also observed for a discrete-time case by (Brechling, $1975,43 \& 101)$. This is based on the assumption that price expectations are stationary (Lucas, 1967; Treadway, 1970). According to Treadway (1970), this expectations hypothesis has many drawbacks, but for deriving a long-run investment function, it is ideal.

Let us follow Gould (1968)'s conclusion and solve (11) for constant prices. We will have the following result.

7 The transversality condition requires $\lim _{t} \rightarrow \infty \partial V_{t} / \partial K_{t}=0 \rightarrow \lim _{t} \rightarrow \infty\left[q_{t}+2 b_{1} I_{t}\right] e^{-s t}=0$. if $r>0$, then $\lim _{t} \rightarrow \infty q_{t} e^{-s t}=0$ and $\lim _{t} \rightarrow \infty \quad\left[2 b_{1} I_{t}\right] e^{-s t}$ also goes to zero. For proof see (Gould, 1968, 51). The Legendre condition requires $\partial(\partial c / \partial K) / \partial K>0$, i.e., $2 b_{1}>0$, which is satisfied, for both conditions (Brechling, 1975, 101). 


$$
\begin{array}{r}
I_{t}=\left(1 / 2 b_{1}\right)\left\{-\left(\delta_{t}+r_{t}\right) q_{t}+\left(1+b_{2}\right) \alpha_{1} K_{t}^{-\alpha_{3} /\left(1-\alpha_{2}\right)} \Omega_{t}\right\} \int_{t}^{\infty} e^{\left(\delta_{t}+r_{t}\right)(t-s)} d_{s} \text { or } \\
I_{t}=\left[\left(1 / 2 b_{1}\right)\left(\delta_{t}+r_{t}\right)\right]\left\{-\left(\delta_{t}+r_{t}\right) q_{t}+\left(1+b_{2}\right) \alpha_{1} K_{t}^{-\alpha_{3} /\left(1-\alpha_{2}\right)} \Omega_{t}\right\} .
\end{array}
$$

From (12) we will have:

$$
\begin{aligned}
\partial I_{t} / \partial K_{t}= & {\left[-\alpha_{3} /\left(1-\alpha_{2}\right)\right]\left[\left(1 / 2 b_{1}\right)\left(\delta_{t}+r_{t}\right)\right]\left(1+b_{2}\right) \alpha_{1} K_{t}^{-\alpha_{3} /\left(1-\alpha_{2}\right)-1} \Omega_{t}<0, } \\
\partial I_{t} / \partial \delta_{t}=- & b_{1} q_{t}\left(\delta_{t}+r_{t}\right)+\left(1 / 2 b_{1}\right)\left(1+b_{2}\right) \alpha_{1} K_{t}^{-\alpha_{3} /\left(1-\alpha_{2}\right)} \Omega_{t}=?, \\
\partial I_{t} / \partial q_{t}=- & \left(1 / 2 b_{1}\right)\left(\delta_{t}+r_{t}\right)^{2} \delta_{t}<0, \\
\partial I_{t} / \partial W_{t}= & \left(1 / 2 b_{1}\right)\left(\delta_{t}+r_{t}\right)\left(1+b_{2}\right) \alpha_{1} K_{t}^{-\alpha_{3} /\left(1-\alpha_{2}\right)}\left[\alpha_{2} /\left(1-\alpha_{2}\right)\right] \alpha_{2}\left(1+b_{2}\right) \\
& A^{\frac{1}{1-\alpha_{2}}}\left[\alpha_{2}\left(1+b_{2}\right) W^{-1}\right]^{\left[\alpha_{2} /\left(1-\alpha_{2}\right)\right]-1} G I_{t}^{\alpha_{3} /\left(1-\alpha_{2}\right)} e^{\alpha_{2} T_{t} /\left(1-\alpha_{2}\right)}>0, \\
\partial I_{t} / \partial r_{t}=- & b_{1} q_{t}\left(\delta_{t}+r_{t}\right)+\left(1 / 2 b_{1}\right)\left(1+b_{2}\right) \alpha_{1} K_{t}^{-\alpha_{3} /\left(1-\alpha_{2}\right)} \Omega_{t}=?, \\
\partial I_{t} / \partial G I_{t}= & \left(1 / 2 b_{1}\right)\left(\delta_{t}+r_{t}\right) \alpha_{3} /\left(1-\alpha_{2}\right)\left(1+b_{2}\right) \alpha_{1} K_{t}^{-\alpha_{3} /\left(1-\alpha_{2}\right)} \\
& A^{\frac{1}{1-\alpha_{2}}}\left[\alpha_{2}\left(1+b_{2}\right) W_{t}^{-1}\right]^{\alpha_{2} /\left(1-\alpha_{2}\right)} G I_{t}^{\left[\alpha_{3} /\left(1-\alpha_{2}\right)\right]-1} e^{\alpha_{2} T_{t} /\left(1-\alpha_{2}\right)}>0, \text { and } \\
\partial I_{t} / \partial T_{t}= & \left(1 / 2 b_{1}\right)\left(\delta_{t}+r_{t}\right) \alpha_{2} /\left(1-\alpha_{2}\right)\left(1+b_{2}\right) \alpha_{1} K_{t}^{-\alpha_{3} /\left(1-\alpha_{2}\right)} \\
& A^{\frac{1}{1-\alpha_{2}}}\left[\alpha_{2}\left(1+b_{2}\right) W^{-1}\right]^{\alpha_{2} /\left(1-\alpha_{2}\right)} G I_{t}^{\alpha_{3} /\left(1-\alpha_{2}\right)} e^{\alpha_{2} T_{t} /\left(1-\alpha_{2}\right)}>0,
\end{aligned}
$$

where $T$ is the technology.

A higher price of capital leads to lower demand for capital and thus, investment. A higher capital results in a lower marginal productivity of capital which lowers investment. The impact of the change in the depreciation rate on investment is an empirical issue. The reason is that a higher depreciation rate requires a higher investment to keep the capital productive, but, at the same time, it also makes the capital more expensive to keep. Therefore, demand for capital (investment) will fall. Consequently, the overall impact cannot be determined theoretically.

A higher price of capital reduces demand for capital/investment due to a substitution effect. A higher wage rate, again due to a substitution effect, results in a higher demand for capital/investment. A higher subjective discount rate leads to a lower present value of the net receipt and thus, a lower investment. However, based on the model, the impact of the change in the discount rate on the investment is an empirical issue. The value of both marginal productivities of labor and capital will increase with government purchases. Consequently, demand for labor and capital and so investment will increase. Finally, the investment demand will increase with technology. 
With the exception of the impact of wage rate on demand for investment, our results are similar to those of Gould (1968) and of Treadway (1970) who find the impact of wage rate to be ambiguous. Other authors use different approaches. For example, Costrell (1983) divides the investment models into supply-constraint and demand-constraint models. In supply-constraint models, the investment demand is governed by the propensity to save out of supply-constraint income. The propensity to save is influenced by interest rate, the return to savings of individuals. In such a world, the interest rate is a function of the firm's profitability and risks, as well as other factors. For example, higher profitability leads to a higher interest rate which brings a higher propensity to save. This, in turn, leads to higher investment.

In demand-constraint models, profitability will increase economic profits (rents) which stimulate investment. Costrell (1983) finds that the aggregate investment behavior under no uncertainty is independent of profitability and the margin between profit and interest or the corporate tax rate. The aggregate investment, under demand uncertainty, will increase, equal zero, or decrease by profitability if the relative risk aversion is increasing, constant, or decreasing, respectively. Since our subjective discount rate does not have any relationship with the profitability, then our results could be similar to those of Costrell, under certainty, in the sense that the profitability does not influence the investment demand.

Following Lucas (1967)'s suggestion for estimation purposes, we need a linear or log linear form of equation (12). Consequently, we will estimate equation (13) as a semi-loglinear approximation of equation (12). Furthermore, since $I$ is $\mathrm{I}(1)$ while $K$ is a $\mathrm{I}(2)$ variable, again following Lucas (1967), we will also estimate the investment per stock of capital $(I / K)$, which is an $\mathrm{I}(1)$ variable, equation (14). Such relationships in log-linear form can be:

$$
L I_{t}=\epsilon_{0}+\epsilon_{1} L K_{t}+\epsilon_{2} \delta_{t}+\epsilon_{3} L q_{t}+\epsilon_{4} L W_{t}+\epsilon_{5} r_{t}+\epsilon_{6} L G I_{t}+\epsilon_{7} T_{t}+u_{t} .
$$

An $L$ before a variable means the logarithm of that variable and $u$ is a disturbance term assumed to be white noise with zero mean. In equation (13), $\epsilon_{i}$ is a constant parameter for $i=0,1$ to 7 , and $\epsilon_{1}<0, \epsilon_{2}<0, \epsilon_{3}<0, \epsilon_{4}>0, \epsilon_{5}<0, \epsilon_{6}>0$, and $\epsilon_{7}>0$.

$$
\frac{I}{K} t=\Omega_{0}+\Omega_{1} \delta_{t}+\Omega_{2} L q_{t}+\Omega_{3} L W_{t}+\Omega_{4} r_{t}+\Omega_{5} L G I_{t}+\Omega_{6} T_{t}+v_{t} .
$$

In equation (14), $v$ is a disturbance term assumed to be white noise with zero mean, $\Omega_{i}$ is a constant parameter for $i=0,1$ to $6, \Omega_{1}<0, \Omega_{2}<0, \Omega_{3}>0, \Omega_{4}<0, \Omega_{5}>0$ and $\Omega_{6}>0$.

Many studies assume the discount rate is constant. For example, Traum \& Yang (2015) assumes a constant discount rate and calibrate it. In reality, the discount rate is subjective and is determined by many factors. To determine the real subjective discount rate $(r)$, let us employ the capital asset pricing model and assume the following security market line. ${ }^{8}$

$$
r_{t}=r_{t}^{*}+\left[R M_{t}-r_{t}^{*}\right] \operatorname{Cov} \cdot\left(r_{t}, R M_{t}\right) / \operatorname{Var} . R M_{t},
$$

${ }^{8}$ A security market line is a linear relationship between the expected rate of return and the risk associated with the security. In other words, the security market line indicates the "going" rate or return in the market for a given amount of risk. The rates of return shown by the security market line are interest rates that have been adjusted for risk. Their magnitudes are determined by the activities of all investors in the market. The market risk premium depends on the attitudes of investors toward bearing risk. 
where $R M$ is the expected market rate and $r^{*}$ is an exogenous riskless real interest rate. The term $\operatorname{Cov} .\left(r_{t}, R M_{t}\right) / \operatorname{Var} . R M_{t}$ is usually defined as $\beta_{t}$ which is an index of the systematic risk. In other words, the $\beta$ variable of a firm measures the sensitivity of the underlying assets' prospects to those of the economy as a whole. Therefore, equation (15) can be written as:

$$
r_{t}=r_{t}^{*}+\left[R M_{t}-r_{t}^{*}\right] \beta_{t}
$$

The current level of $R M$ reflects investors' current feelings about the prospects for the economy. We can assume that investors' expectations for the economy are affected by the values of fundamental economic variables such as productivity growth, expected future taxes, which are affected themselves by both fiscal and monetary variables like government expenditure, debt, deficits, foreign financing of the government debt and interest rates. Variables which influence systematic risk include corporate taxes, business environment and uncertainty. Consequently, we assume $\left[R M_{t}-r_{t}^{*}\right] \beta_{t}$ has the following linear form:

$$
\left[R M_{t}-r_{t}^{*}\right] \beta_{t}=c_{0}+c_{1} r_{t}^{*}+c_{2} G g d p_{t}+c_{3} \text { Defgdp }+c_{4} \text { Debtgdp } p_{t}+c_{5} \text { Fdebtgdp },
$$

where $c$ 's are constant coefficients, $r_{t}^{*}$ is the real corporate paper rate, $G g d p$ is the federal government expenditures on goods and services per GDP, Defgdp is the federal deficit per GDP, Debtgdp is the outstanding federal debt per GDP, and Fdebtgdp is the federal foreignfinanced debt per GDP. Note that, for the sake of simplicity, we have assumed there is only a lump-sum tax. ${ }^{9}$ Ggdp, Defgdp, Debtgdp and Fdebtgdp reflect the fiscal policy. Defgdp and Debtgdp reflect the volatility of the interest rate caused by domestic shock. Clearly, the bigger the size of the government (the more $G g d p$ ) is, the more the crowding out of private investment is and the higher the discount rate will be. Furthermore, a higher Defgdp or Debtgdp reflects the future tax, or more future government debt and/or the monetization of debt, which implies a higher inflation rate, and results in a higher $R M$ and, therefore, the discount rate. Consequently, we assume these variables are also determinants of business environment and uncertainty.

Except for $c_{5}$, all $c$ 's are positive. The sign of $c_{5}$ is an empirical issue because a higher foreign-financed debt (Fdebtgdp) will put a higher pressure on the value of the domestic currency, which by itself can make exports more expensive and imports cheaper, resulting in a higher negative balance of trade. This could put upward pressure on the subjective discount rate. However, the more government finances its debt by foreign investment, the more domestic saving is available for domestic investment and, therefore, a higher foreignfinanced debt stock can result in a lower discount rate. Consequently, the net impact of foreign-financed debt is an empirical issue. Moreover, $r^{*}$ reflects the outstanding corporate debt, which, due to a tight corporate debt financing, puts upward pressure on the discount rate. Furthermore, the tighter the monetary policy is, the higher the Effective Fed Fund rate will be, which puts upward pressure on $r^{*}$ (discount rate). Consequently, $r^{*}$ also reflects the monetary policy.

9 Although the literature typically uses fiscal variables of all (federal and local) governments, following Traum \& Yang $(2015,31)$, I use fiscal variables of the federal government only. As explained by the authors, that is "because state and local governments generally have balanced-budget rules of various forms, fiscal financing decisions are likely to differ across federal and state and local governments." 
Substitute (17) in (16) to get: ${ }^{10}$

$$
r_{t}=c_{0}+\left(1+c_{1}\right) r_{t}^{*}+c_{2} G g d p_{t}+c_{3} \text { Defgdp }+c_{4} \text { Debtgdp } p_{t}+c_{5} \text { Fdebtgdp } .
$$

Substitute (18) in (13) and (14) to get the following equations:

$$
\begin{array}{r}
L I_{t}=\Psi_{0}+\Psi_{1} L K_{t}+\Psi_{2} \delta_{t}+\Psi_{3} L q_{t}+\Psi_{4} L W_{t}+\Psi_{5} r_{t}^{*}+\Psi_{6} G g d p_{t}+\Psi_{7} \text { Defgdp } \\
+\Psi_{8} \text { Debtgdpt }+\Psi_{9} F \text { debtgdp } p_{t}+\Psi_{10} L G I_{t}+\Psi_{11} T_{t}+u_{t},
\end{array}
$$

where all $\Psi$ 's are constant and $\Psi_{0}=\epsilon_{0}+\epsilon_{5} c_{0}, \Psi_{1}=\epsilon_{1}<0, \Psi_{2}=\Psi_{2}<0, \Psi_{3}=\epsilon_{3}<0$, $\Psi_{4}=\epsilon_{4}>0, \Psi_{5}=\epsilon_{5}\left(1+c_{1}\right)<0, \Psi_{6}=\epsilon_{5} c_{2}<0, \Psi_{7}=\epsilon_{5} c_{3}<0, \Psi_{8}=\epsilon_{5} c_{4}<0$, $\Psi_{9}=\epsilon_{5} c_{5}=?, \Psi_{10}=\epsilon_{6}>0$ and $\Psi_{11}=\epsilon_{7}>0$.

$$
\begin{array}{r}
\frac{I}{K} t=\Phi_{0}+\Phi_{1} \delta_{t}+\Phi_{2} L q_{t}+\Phi_{3} L W_{t}+\Phi_{4} r_{t}^{*}+\Phi_{5} G g d p_{t}+\Phi_{6} \text { Defgdp } \\
+\Phi_{7} \text { Debtgdp }_{t}+\Phi_{8} F \text { debtgdp }+\Phi_{9} L G I_{t}+\Phi_{10} T_{t}+v_{t}
\end{array}
$$

where $\Phi_{0}=\Omega_{0}, \Phi_{1}=\Omega_{1}<0, \Phi_{2}=\Omega_{2}<0, \Phi_{3}=\Omega_{3}>0, \Phi_{4}=\Omega_{4}\left(1+c_{1}\right)<0$, $\Phi_{5}=\Omega_{4} c_{2}<0, \Phi_{6}=\Omega_{4} c_{3}<0, \Phi_{7}=\Omega_{4} c_{4}<0, \Phi_{8}=\Omega_{4} c_{5}=?, \Phi_{9}=\Omega_{5}>0$ and $\Phi_{10}=\Omega_{6}>0$. As before, $u$ and $v$ are disturbance terms which are assumed to be white noise with zero mean. In the next section, we estimate equations (19) and (20).

\section{Data, Empirical Methodology and Estimation Results}

\subsection{Data}

The model is estimated by using quarterly US data for the sample period 1970Q12017Q4. The choice of the period is based on the availability of the data. Some variables, e.g., the federal debt held by the public is available from 1970. The deficit is calculated as government expenditures minus government revenue. All data are taken from the St. Louis Federal Reserve Database (FRED).

The data on the capital stock is available annually up to 2017. This data is in millions of 2011 US dollars. We convert the observations in billion chained 2011. Data on the depreciation rate of capital and the price of capital is taken from the Penn World Table (www.ggdc.net/pwt). Data ends in 2017. The annual data on capital, based on Chow \& Lin (1971)'s approach, is interpolated to get quarterly data.

All observations are seasonally adjusted and in billions of dollars, when appropriate. When seasonally adjusted observations are not available, the variables, using RATS computer package, are seasonally adjusted. The corporate rate is Corporate Bond Yield (Moody's AAA), the average of daily from FRED. The real corporate rate, following Bernanke (1983) and Alesina et al. (2002), among others, is the corporate rate minus quarter ahead inflation rate of GDP price index. During the sample period, we have four exogenous shocks which could influence the investment decision. We allow these shocks to affect the short-run dynamics of the system. The first two shocks are tax reforms of 1986 and 2003.

10 One may argue that the discount rate may also be affected by the bubbles in the share price of the firm. However, Chirinko \& Schaller (1996) shows, by testing the Euler equation, that there is no correlation between investment and stock market bubbles, at least for the US. 
The Tax Reform Act of 1986, which was referred to as the second of the two "Reagan tax cuts", was enacted on October 22, 1986, to simplify the income tax code. It broadened the tax base and eliminated many tax shelters. Since this tax reform resulted in the increase of corporate taxes, capital gains taxes and miscellaneous excises, it could affect the private investment. A dummy variable, Taxreform 86 , which is equal to one for $1984 \mathrm{Q} 1$ and after and zero otherwise, is created. The second tax reform, which could influence the private investment, is the Jobs and Growth Tax Relief Reconciliation Act of 2003 (or the "Bush Tax Cut"). It was passed by the United States Congress on May 23, 2003, and signed into law by President George W. Bush on May 28, 2003. Nearly all of the cuts (individual rates, capital gains, dividends, estate tax) were set to expire after 2010. A dummy variable, BushTcut, which is equal to one for the period 2003Q3-2010Q4 and zero otherwise, is created to reflect this tax reform.

The other two shocks are the North American Free Trade Act (NAFTA) and the financial crisis in 2007. NAFTA went into effect on January $1^{\text {st }}, 1994$. This act provides unprecedented freedom in trade among the United States, Canada and Mexico. A dummy variable, Nafta, which is equal to one for 1994Q1 and after and zero otherwise, is created. To capture the US financial crises, a dummy variable, USCRISIS, which is equal to one for the period of 2007Q4 and 2009Q3 and zero, otherwise, is introduced.

\subsection{Long-Run Empirical Methodology and Result}

To investigate the stationarity property of the variables, we use Augmented Dickey-Fuller and non-parametric Phillips-Perron tests, and Zivot \& Andrews (1992) and Lee \& Strazicich (2001, 2003) tests for the possibility of breaks in intercept and slope. All these tests show that all series, except for the capital stock, are I(1) (non-stationary). They are, however, the first-difference stationary. The capital stock is $\mathrm{I}(2) \cdot{ }^{11}$

The long-run estimation results of Johansen-Juselius Maximum Likelihood estimation of equation (19) are reported in Table A.1. The long-run estimation results of JohansenJuselius Maximum Likelihood estimation of equation (20), as well as the Fully Modified Ordinary Least Squares (FMOLS) of this equation, are reported in Table A.2. The FMOLS estimation is originally introduced by Phillips \& Hansen (1990), but we use its extension from Hansen (1992). FMOLS first estimates the cointegrating vector by least squares and then does a non-parametric correction for small-sample endogeneity.

We use the multiple structural change test by Bai \& Perron (2003). According to the test results, the breaks are 1983Q4 and 2008Q4; the former of which is associated with the long-awaited recovery after the second oil shock of 1979-80 and the latter is associated with the US crisis. We allow for these breaks in the long-run equation. The lag length is determined to induce white noise property in the residuals. Following (Hansen \& Juselius, 1995, 26), we set $p=r$ and test for autocorrelation and ARCH. $\operatorname{LM}(1)$ and $\operatorname{LM}(2)$ statistics are employed to confirm the choice of lag length. The order of cointegration (r) will be determined by using Trace tests developed in Johansen \& Juselius (1992).

Note that we also allow the short-run dynamics of the system to be affected by the NAFTA agreement, tax reforms of 1986 and 2003 and the US financial crisis by using the dummy variables introduced above. Because we allow the short-run dynamics of the system

\footnotetext{
${ }^{11}$ For the sake of brevity, these results are not reported but are available upon request.
} 
to be affected by these dummy variables, we need to simulate the critical values as well as their associated p-values for the rank test. The critical values of the test statistics are calculated based on the length of the random walk of 400 with 2,500 replications and using the Bartlett correction factor, the Trace test has been corrected for the small sample error (Johansen, 2000, 2002).

Table A.1 reports long-run cointegration result of equation (19). Based on the Trace test result shown in the first panel of Table A.1, there are six cointegration relationships in space. According to the diagnostic test, there is no autocorrelation or ARCH heteroscedasticity with the lag length of 6 . However, the error is not normally distributed, but as Johansen (1995b) states, a departure from normality is not very serious in cointegration tests.

Since we find more than one cointegrating relationship, we need to identify the estimated cointegrating vectors. In this way, the estimated coefficients of cointegrating equations will be economically meaningful and ensure uniqueness of all coefficients. Following Johansen \& Juselius (1992) and Johansen (1995a), among many others, we can test for the existence of possible economic hypotheses among the cointegrating vectors in the system. The middle panel of Table A.1 reports the identified relationships. As the Chi-squared values indicate, restrictions are jointly accepted, the system is identified à la Johansen (1995a)'s Theorem $3 .^{12}$ Namely, generic (which is related to the linear statistical model and requires the rank condition) and empirical identifications are satisfied, see Johansen \& Juselius (1992).

We test for the stability of all coefficients. We find all tests and coefficients are stable. ${ }^{13}$ We then proceed to analyze the identified long-run equations. The choice of normalization to get standard errors ( $t$-statistics) is limited as we could only normalize investment and capital stock variables. The rest is determined by the system. The first row of the lower panel of Table A.1 reports the long-run investment function. We need to restrict the government expenditure and investment, as well as breaks and trend to ensure an identified equation. As we can see all coefficients, except for the coefficient of the debt per GDP, which is also zero, are statistically significant, and all, but the stock of capital, price of capital and debt per GDP, confirm our theoretical model. Noting that this is a long-run cointegration relationship, one possible explanation for the positive relationship between the stock of capital and investment is that higher investment results in a higher capital as the next identified equation also indicates. Furthermore, one possible explanation for the positive relationship between the price of capital and investment over the long run is that a higher price of capital leads to a higher supply of capital over the long run, which requires higher investment. As we can see, the estimated long-run coefficients of federal government deficit and foreign-financed debt confirm our theoretical finding. ${ }^{14}$ Therefore, government debt will crowd out private investment.

The second identified equation resembles demand for capital. As investment goes up, this demand shifts to the right and, as we expect, demand for capital will go up. A higher depreciation, as also expected, shifts this demand to the right. The third identified equation states the relationship between depreciation and government investment. A higher stock of capital and wage rate shift this relationship down indicating a higher government investment for a given depreciation rate. The reverse is true for a higher price of capital.

12 Note that if the system is not identified, we could never estimate the $t$ values.

13 For the sake of brevity, these results are not reported, but they are available upon request.

14 Note that, according to our model, the sign of foreign-financed debt is an empirical issue. 
The fourth identified equation shows the relationship between government investment and the price of capital. A higher depreciation shifts the curve down and to the right, indicating a lower price of capital for the given government investment. This is also true for a higher wage rate. A higher government expenditure, deficit and debt, all per GDP, will increase government investment for a given price of capital. A higher real interest rate will shift the curve up, indicating a higher price of capital for the given government investment. This is also true for a higher foreign-financed debt stock. The fifth identified equation is the determinants of government expenditure. As real interest rate, deficit, foreign-financed debt and government investment go up, government expenditure will go up certainly. Surprisingly, as the wage rate goes up, this expenditure will go down. The last identified equation is the long-run determinants of deficit per GDP. According to this equation, government investment and debt will increase the deficit per GDP, but the interest rate lowers this variable very poorly (coefficient is very small and close to zero).

Table A.2 reports long-run cointegration results of equation (20). According to Bai \& Perron (2003)'s test, the results indicate that there are two breaks over the long run. These breaks are 1991Q4 and 2008Q4, which are associated with Iraq's invasion and the US financial crisis, respectively. Based on the Trace test results shown in the first panel of the table, there are five cointegration relationships in space. According to the diagnostic test, there is no autocorrelation or $\mathrm{ARCH}$ heteroscedasticity with the lag length of 6 . However, the error term is not again normally distributed, but, as it is mentioned above, a departure from normality is not serious in the cointegration tests. Furthermore, we could only normalize $I / K$ variable in equation (20). The rest of the normalizations is determined by the system in order to get standard errors ( $t$ statistics) for the estimated coefficients. Consequently, while the system is generic and empirically identified, except for the $I / K$ equation, none of the other identified equations in the lower panel of Table A.2 is economically identified. Therefore, we analyze the first fully identified equation $(I / K)$.

Except for the coefficient of government investment, all other coefficients are statistically significant. The coefficients of the price of capital, wage rate, government expenditure and deficit do not confirm our theoretical model. A possible explanation for this result is that a higher price of capital reduces the demand for capital and so the ratio of the investment to the stock of capital increases. One possible explanation for the negative impact of the wage rate on the investment-to-capital stock ratio is that a higher wage rate increases the cost of private investment and reduces this ratio. The positive impact of government expenditure on this ratio implies that government expenditure does not crowd out private investment. This is also true for deficit per GDP. However, as our theoretical model indicates and the estimated coefficients of government debt and foreign-financed debt imply, debt and foreignfinanced debt crowd out private investment.

To check the robustness of our results, we also estimate equation (20) by Fully Modified Least Squared (FMLS). In FMLS, we do not need to restrict any coefficient. ${ }^{15}$ Interestingly, the estimation result confirms most of the theoretical model on fiscal policy. Namely, government expenditure, deficits and debt crowd out private investment per the stock of capital, even though the coefficient of government expenditure is not statistically significant. Foreign-financed debt has a very low positive effect on investment per the stock of capital,

15 The full regression result is not reported but is available upon request. 
while the coefficient of government investment is not statistically significant.

Since we cannot have a variable which is I(2) in the FMLS, we also drop the capital stock from equation (19) and estimate the model. Interestingly, while the impact of the real interest rate is positive and statistically significant $(0.011, t-$ stat. $=3.63)$, the impact of government expenditure $(-9.57, t-$ stat. $=-2.78)$, deficits $(-5.60, t-s t a t .=-2.47)$ and debt $(-0.01, t-$ stat. $=-3.43)$ is negative and statistically significant. Foreign-financed debt has a negative and statistically significant $(-0.01, t-$ stat. $=-2.74)$ effect, but government investment has a negative effect on the level of the private investment, although it is not statistically significant $(-0.08, t-$ stat. $=-0.53)$. This result further confirms that government expenditure, deficit and debt crowd out private investment, while this is not the case for the government investment. These results also verify our theoretical finding of equation (19) and our empirical results reported in Table A.1.

The overall result is that government investment does not have any impact on private investment, but government expenditure, deficit and debt do crowd out the private investment over the long run. This result confirms the findings of Alesina et al. (2002), who conclude that a fall in government expenditure results in an increase in investment per the stock of capital in OECD countries. Link (2006) also finds that government expenditure crowds out domestic investment in the US. Our result that public investment does not have any long-run impact on private investment contradicts the finding of Aschauer (1989), who states that public investment crowd in private investment in the US.

\subsection{Short-Run Error Correction Estimation Result}

Table A.3 reports the parsimonious estimation of the final error correction model (ECM) that is implied by the cointegrating vector on the basis of Hendry's General-to-Specific approach. We allow a lag profile of eight quarters at the original ECM. To calculate the error correction term, we use the cointegrating vector estimated for the ratio of investment to the stock of capital $(I / K)$, reported in the lower panel of Table A.2. Note that since the capital stock is $\mathrm{I}(2)$, we cannot use the cointegrating vector reported in the lower panel of Table A.1 as the variables in ECM should all be $\mathrm{I}(0)$.

Following Granger (1986), we should note that if small equilibrium errors can be ignored while reacting to large ones substantially, the error correcting equation is nonlinear. We, therefore, incorporate all possible kinds of non-linear specifications, i.e., squared, cubed and fourth powered of the equilibrium errors (with statistically significant coefficients), as well as the products of those significant equilibrium errors. As Hansen's stability tests indicate, the variance and all coefficients individually and jointly with variance are stable.

The non-linear error-correction term indicates that the agents may ignore small deviations from equilibrium but react drastically to larger deviations from the equilibrium. The change in the price of capital increases the change in investment per stock of capital $(\Delta I / K)$. However, after four quarters it reduces it and in the fifth quarter it increases it again. The overall conclusion (summation of these coefficients) is that the change in the price of capital will increase $\Delta I / K$ over the short run. The change of the deficits per GDP will increase $\Delta I / K$ after six quarters. The total effect of the change in debt per GDP over the short run is an increase in the $\Delta I / K$ ratio. The interest rate will reduce, like over the long run, the change of investment per stock of capital. As we expect, during the US crisis of 20072009 investment fell in the US. The overall conclusion is that while debt does not have any impact over the short run on the investment, the interest rate has a negative effect on investment. 


\section{Conclusions}

In this paper, an aggregate private investment function for an economy in which firms incur adjustment costs is derived and tested on US data for the period 1970Q1-2017Q4. The study provides evidence that over the long run public investment does not have any impact on private investment, but government expenditure, deficit and debt do crowd out the private investment. For instance, a higher deficit can be viewed by investors as future taxes and/or a higher money supply if the deficit is monetized. Thus, it results in higher expected inflation and other disturbances in the economy. Consequently, deficits can positively influence investors' discount rates and reduce private investment over the long run. However, over the short run, the deficit does not have any impact on private investment, and government debt will increase private investment.

Furthermore, this paper provides evidence that the foreign-financed debt has a negative effect on the private investment over the long run, but no effect over the short run. Consequently, debt management over the long run should be watched and paid special attention to. It is found that the price of capital can have a positive impact on private investment both over the short and long run. The paper also shows that the wage rate can increase the level of investment but lowers the ratio of investment to the stock of capital in the long run. However, it does not have any effect on this ratio over the short run.

It is found that while a higher real interest rate can lower the level of domestic investment, as well as the ratio of investment to the stock of capital over the long run, it does not have any effect on the latter over the short run. Interestingly, public investment, as evidenced in this paper, can increase the level of capital over the long run. The study also shows that, in the US, government spending per GDP will increase by a higher interest rate, deficit per GDP, foreign-financed debt per GDP and public investment over the long run. However, the reverse is true for the debt per GDP. Interestingly, it is found a higher interest rate can lower deficit per GDP over the long run, but a higher public debt per GDP and public investment per GDP result in a higher deficit per GDP over the long run.

I would suggest the above model be adjusted for a small country and tested on the related data. The results could possibly be compared to the result of this paper, which is for a large country. In this way, the existing literature can be extended.

\section{References}

Abiad, A., Furceri, D., \& Topalova, P. (2016). The Macroeconomic Effects of Public Investment: Evidence from Advanced Economies. Journal of Macroeconomics(50), 224240. doi:10.1016/j.jmacro.2016.07.005

Afonso, A., \& St. Aubyn, M. (2009). Macroeconomic Rates of Return of Public and Private Investment: Crowding-In and Crowding-Out Effects. The Manchester School, 7r(Supplement), 21-39. doi:10.1111/j.1467-9957.2009.02117.x

Ahmed, S. (1986). Railway Reforms: Do They Influence Operating Efficiency? Journal of Monetary Economics, 17(2), 197-224. doi:10.1016/0304-3932(86)90028-0

Alesina, A., Ardagna, S., Perotti, R., \& Schiantarelli, F. (2002). Fiscal Policy, Profits, and Investment. American Economic Review, 92(3), 571-589. doi: $10.1257 / 00028280260136255$ 
Allen, R. G. (1967). Macro-Economic Theory. London, The Macmillan Press Ltd.

Ardagna, S., Caselli, F., \& Lane, T. (2007). Fiscal Discipline and the Cost of Public Debt Service: Some Estimates for OECD Countries. The B.E. Journal of Macroeconomics, 7(1), 1-33. doi:10.2202/1935-1690.1417

Aschauer, D. A. (1989). Does Public Capital Crowd Out Private Capital? Journal of Monetary Economic, 24(2), 171-188. doi:10.1016/0304-3932(89)90002-0

Azzimonti, M., De Francisco, E., \& Quadrini, V. (2014). Financial Globalization, Inequality, and the Rising Public Debt. American Economic Review, 104(8), 2267-2302. doi:10.1257/aer.104.8.2267

Bai, J., \& Perron, P. (2003). Computation and Analysis of Multiple Structural Change Models. Journal of Applied Econometrics, 18(1), 1-22. doi:10.1002/jae.659

Barro, R. J. (1981). Output Effects of Government Purchases. Journal of Political Economy, 89(6), 1086-1121. doi:10.1086/261024

Barth, J. R., Iden, G., Russek, F. S., \& Wohar, M. (1991). The Effects of Federal Budget Deficits on Interest Rates and the Composition of Domestic Output. In R. G. Penner (Ed.), The Great Fiscal Experiment (pp. 71-141). The Urban Institute Press: Washington, DC.

Bernanke, B. S. (1983). Irreversibility, Uncertainty, and Cyclical Investment. The Quarterly Journal of Economics, 98(1), 85-106. doi:10.2307/1885568

Blackley, P. R. (2014). New Estimates of Direct Crowding out (or in) of Investment and of a Peace Dividend for the U.S. Economy. Journal of Post Keynesian Economics, 37(1), 67-90. doi:10.2753/PKE0160-3477370106

Brechling, F. (1975). Investment and Employment Decisions. Manchester, Manchester University Press.

Cheung, Y.-W., \& Lai, K. S. (1993). Finite Sample Sizes of Johansen's Likelihood Ratio Tests for Cointegration. Oxford Bulletin of Economics and Statistics, 55(3), 313-328. doi:10.1111/j.1468-0084.1993.mp55003003.x

Chirinko, R. S., \& Schaller, H. (1996). Bubbles, Fundamentals, and Investment: A Multiple Equation Testing Strategy. Journal of Monetary Economics, 38(1), 47-76. doi:10.1016/0304-3932(96)01267-6

Chow, G. C., \& Lin, A. (1971). Best Linear Unbiased Interpolation, Distribution, and Extrapolation of Time Series by Related Series. The Review of Economics and Statistics, 53(4), 372-375. doi:10.2307/1928739

Claeys, P., Moreno, R., \& Suriñach, J. (2012). Debt, Interest Rates, and Integration of Financial Markets. Economic Modelling, 29(1), 48-59. doi:10.1016/j.econmod.2011.05.009

Cogan, J. F., Cwik, T., Taylor, J. B., \& Wieland, V. (2010). New Keynesian versus Old Keynesian Government Spending Multipliers. Journal of Economic Dynamics 86 Control, 34(3), 281-295. doi:10.1016/j.jedc.2010.01.010

Costrell, R. M. (1983). Profitability and Aggregate Investment under Demand Uncertainty. The Economic Journal, 93(369), 166-181. doi:10.2307/2232171

Desroches, B., \& Francis, M. (2010). World Real Interest Rates: A Global Savings and Investment Perspective. Applied Economics, 42(22), 2801-2816. doi:10.1080/00036840801964690 
Eisner, R., \& Strotz, R. H. (1963). Determinants of Business Investment. In D. B. S. et al. (Ed.), Impacts of monetary policy (a series of research studies for the Commission on Money and Credit ed., pp. 59-338). Prentice-Hall.

Elmendorf, D., \& Mankiw, N. G. (1999). Government Debt. In J. Taylor \& M. Woodford (Eds.), Handbook of macroeconomics (pp. 1615-1669). Elsevier Science: Amsterdam.

Engen, E., \& Hubbard, G. (2005). Federal Government Debt and Interest Rates. In M. Gertler \& K. Rogoff (Eds.), Nber macroeconomics annual 2004 (pp. 83-160). MIT Press: Cambridge, MA.

Engle, R. F. (1982). Autoregressive Conditional Heteroscedasticity with Estimates of the Variance of United Kingdom Inflation. Econometrica, 50(4), 987-1007. doi: $10.2307 / 1912773$

Forni, L., Monteforte, L., \& Sessa, L. (2009). The General Equilibrium Effects of Fiscal Policy: Estimates for the Euro Area. Journal of Public Economics, 93(3-4), 559-585. doi:10.1016/j.jpubeco.2008.09.010

Gale, W. G., \& Orszag, P. R. (2004). Budget Deficits, National Saving, and Interest Rates. Brookings Papers on Economic Activity, 35, 101-210. doi:10.1353/eca.2005.0007

Godfrey, L. G. (1978). Testing Against General Autoregressive and Moving Average Error Models when the Regressors Include Lagged Dependent Variables. Econometrica, 46(7), 1293-1301. doi:10.2307/1913829

Godfrey, L. G. (1988). Misspecification Test in Econometrics. Cambridge: Cambridge University Press.

Gould, J. P. (1968). Adjustment Costs in the Theory of Investment of the Firm. Review of Economic Studies, 35(1), 47-55. doi:10.2307/2974406

Granger, C. W. J. (1986). Developments in the Study of Cointegrated Economic Variables. Oxford Bulletin of Economics and Statistics, 48(3), 213-218. doi:10.1111/j.14680084.1986.mp48003002.x

Hansen, B. E. (1992). Efficient Estimation and Testing of Cointegrating Vectors in the Presence of Deterministic Trends. Journal of Econometrics, 53(1-3), 87-121. doi:10.1016/0304-4076(92)90081-2

Hansen, H., \& Juselius, K. (1995). CATS in RATS Cointegration Analysis of Time Series. Evanston, IL: Estima.

Hercowitz, Z. (1986). The Real Interest Rate and Aggregate Supply. Journal of Monetary Economics, 18(2), 121-145. doi:10.1016/0304-3932(86)90072-3

Jarque, C. M., \& Bera, A. K. (1987). A Test for Normality of Observations and Regression Residuals. International Statistical Review, 55(2), 167-172. doi:10.2307/1403192

Johansen, S. (1995a). Identifying Restrictions of Linear Equations With Applications to Simulations Equations and Cointegration. Journal of Econometrics, 69(1), 111-132. doi:10.1016/0304-4076(94)01664-L

Johansen, S. (1995b). Likelihood-Based Inference in Cointegrated Vector Autoregressive Models. Oxford University Press, Oxford.

Johansen, S. (2000). A Bartlett Correction Factor for Test on the Cointegration Relations. Econometric Theory, 16(5), 740-778. doi:10.1017/S0266466600165065 
Johansen, S. (2002). A Small Sample Correction of the Test of Cointegrating Rank in the Vector Autoregressive Model. Econometrica, 70(5), 1929-1961. doi:10.1111/14680262.00358

Johansen, S., \& Juselius, K. (1992). Testing Structural Hypotheses in a Multivariate Cointegration Analysis of the PPP and the UIP for UK. Journal of Econometrics, 53(13), 211-244. doi:10.1016/0304-4076(92)90086-7

Kameda, K. (2014). Budget Deficits, Government Debt, and Long-term Interest Rates in Japan. Journal of the Japanese and International Economies, 32(C), 105-124. doi:10.1016/j.jjie.2014.02.001

Laubach, T. (2009). New Evidence on the Interest Rate Effects of Budget Deficits and Debt. Journal of the European Economic Association, 7(4), 858-885. doi:10.1162/JEEA.2009.7.4.858

Lee, J., \& Strazicich, M. C. (2001). Break Point Estimation and Spurious Rejections with Endogenous Unit Root Tests. Oxford Bulletin of Economics and Statistics, 63(5), 535-558. doi:10.1111/1468-0084.00234

Lee, J., \& Strazicich, M. C. (2003). Minimum Lagrange Multiplier Unit Root Test with Two Structural Breaks. The Review of Economics and Statistics, 85(4), 1082-1089. doi:10.1162/003465303772815961

Leeper, E. M., Plante, M., \& Traum, N. (2010). Dynamics of Fiscal Financing in the United States. Journal of Econometrics, 156(2), 304-321. doi:10.1016/j.jeconom.2009.11.001

Link, S. B. (2006). Do Government Purchases Crowd out Investment? International Review of Economics, 53(3), 323-333. doi:10.1007/BF03029784

Lucas, R. E. J. (1967). Adjustment Costs and the Theory of Supply. The Journal of Political Economy, 75 (4), 321-334. doi:10.1086/259289

Phillips, P. C. B., \& Hansen, B. E. (1990). Statistical Inference in Instrumental Variables Regression with I(1) Processes. The Review of Economic Studies, 57(1), 99-125. doi: $10.2307 / 2297545$

Ramey, V. A. (2019). Ten Years after the Financial Crisis: What Have We Learned from the Renaissance in Fiscal Research? Journal of Economic Perspectives, 33(2), 89-114. doi:10.1257/jep.33.2.89

Ramsey, J. B. (1969). Tests for Specification Errors in Classical Linear Least-Squares Regression Analysis. Journal of Royal Statistical Society, Series B, 31(2), 350-371. doi:10.1111/j.2517-6161.1969.tb00796.x

Ratto, M., Roeger, W., \& Veld, J. I. (2009). QUEST III: An Estimated Open-Economy DSGE Model of the Euro Area with Fiscal and Monetary Policy. Econometric Modelling, 26(1), 222-233. doi:10.1016/j.econmod.2008.06.014

Rothschild, M. (1971). On the Cost of Adjustment. The Quarterly Journal of Economics, 85(4), 605-622. doi: $10.2307 / 1882270$

Salotti, S., \& Trecroci, C. (2016). The Impact of Government Debt, Expenditure and Taxes on Aggregate Investment and Productivity Growth. Economica, 83(330), 356-384. doi:10.1111/ecca. 12175

Scarth, W. M. (1984). Adjustment Costs and Aggregate Supply Theory. Canadian Journal of Economics, 17(4), 847-854. doi:10.2307/135077 
Söderström, H. T. (1976). Production and Investment Under Costs of Adjustment A Survey. Zeitschrift für Nationalökonomie, 36(3-4), 369-388. doi:10.1007/BF01287519

Traum, N., \& Yang, S.-C. S. (2015). When Does Government Debt Crowd Out Investment? Journal of Applied Econometrics, 30(1), 24-45. doi:10.1002/jae.2356

Treadway, A. B. (1970). Adjustment Costs and Variable Inputs in the Theory of the Competitive Firm. Journal of Economic Theory, 2(4), 329-347. doi:10.1016/00220531(70)90017-7

Uhlig, H. (2010). Some Fiscal Calculus. American Economic Review, 100(2), 30-34. doi:10.1257/aer.100.2.30

White, H. (1980). A Heteroskedasticity Consistent Covariance Matrix Estimator and a Direct Test for Heteroskedasticity. Econometrica, 48(4), 817-837. doi:10.2307/1912934

Wisley, T. O., \& Johnson, S. R. (1985). An Evaluation of Alternative Investment Hypotheses using Non-Nested Tests. Southern Economic Journal, 52(2), 422-430. doi:10.2307/1059628

Zivot, E., \& Andrews, D. W. K. (1992). Further Evidence on the Great Crash, the Oil Price Shock, and the Unit-Root Hypothesis. Journal of Business and Economic Statistics, 10(3), 3851-3874. doi:10.2307/1391541 
Appendix: Regression Results

Table A.1: Long-Run Test Results ${ }^{a}$

\begin{tabular}{|c|c|c|c|c|c|c|c|c|c|c|c|c|c|c|}
\hline \multicolumn{15}{|c|}{$\begin{array}{c}\text { The Model with I(2) Variable Specified by equation (19) } \\
\text { Tests of the Cointegration Rank }(\rho)\end{array}$} \\
\hline$H_{0}=\rho$ & $\mathbf{0}$ & 1 & 2 & 3 & 4 & 5 & 6 & 7 & 8 & 9 & 10 & \multicolumn{3}{|c|}{ Diagnostic tests ${ }^{b} p$-value } \\
\hline $\begin{array}{l}\text { Rank test } \\
\text { statistics }\end{array}$ & 986 & 659 & 965 & 334 & 229 & 139 & 68 & 9 & -0.38 & -65 & -80 & \multirow{2}{*}{\multicolumn{3}{|c|}{$\begin{array}{l}\text { Autocorrelation } \\
\operatorname{LM}(1): 0.0 \\
\operatorname{LM}(2): 0.08 \\
\text { ARCH } \\
\mathrm{LM}(1): 0.23 \\
\mathrm{LM}(2): 0.10 \\
\text { Normality: } 0.0 \\
\text { Lag length }=\mathbf{6}\end{array}$}} \\
\hline$p$-value & 0.0 & 0.0 & 0.0 & 0.0 & 0.0 & 0.03 & $0.93^{c}$ & 1.0 & $(\mathrm{NA})$ & $(\mathrm{NA})$ & $(\mathrm{NA})$ & & & \\
\hline \multicolumn{15}{|c|}{ Identified Long-Run Relationships for $\rho=6, \chi^{2}(4)=7.04(0.13)$. Estimating restricted Beta: } \\
\hline Normalized & $L I$ & $L K$ & $\delta$ & $L q$ & $L w$ & $r^{*}$ & Ggdp & $D e f g d p$ & Debtgdp & Fdebtgdp & $L G I$ & $\mathrm{~T}(' 83: 04)$ & $\mathrm{T}(' 08: 04)$ & Trend \\
\hline $\begin{array}{l}L I \\
(t-s t a t)\end{array}$ & - & $\begin{array}{l}0.05 \\
(5.19)\end{array}$ & $\begin{array}{l}-0.61 \\
(-0.52)\end{array}$ & $\begin{array}{c}0.51 \\
(58.77)\end{array}$ & $\begin{array}{c}2.2 \\
(48.6)\end{array}$ & $\begin{array}{l}-0.001 \\
(-1.93)\end{array}$ & $\begin{array}{c}0 \\
(\mathrm{NA})\end{array}$ & $\begin{array}{c}-16.2 \\
(-38.64)\end{array}$ & $\begin{array}{c}0 \\
(1.26)\end{array}$ & $\begin{array}{l}-0.003 \\
(-5.48)\end{array}$ & $\begin{array}{c}0 \\
(\mathrm{NA})\end{array}$ & $\begin{array}{c}0 \\
(\mathrm{NA})\end{array}$ & $\begin{array}{c}0 \\
(\mathrm{NA})\end{array}$ & $\begin{array}{c}0 \\
(\mathrm{NA})\end{array}$ \\
\hline $\begin{array}{l}L K \\
(t-s t a t)\end{array}$ & $\begin{array}{c}2.52 \\
(94.09)\end{array}$ & - & $\begin{array}{l}128.62 \\
(29.28)\end{array}$ & $\begin{array}{c}-1.75 \\
(-35.41)\end{array}$ & $\begin{array}{c}0 \\
(\mathrm{NA})\end{array}$ & $\begin{array}{c}0 \\
(\mathrm{NA})\end{array}$ & $\begin{array}{c}0 \\
(\mathrm{NA})\end{array}$ & $\begin{array}{c}0 \\
(\mathrm{NA})\end{array}$ & $\begin{array}{c}0 \\
(\mathrm{NA})\end{array}$ & $\begin{array}{l}0.001 \\
(1.13)\end{array}$ & $\begin{array}{c}0.54 \\
(7)\end{array}$ & $\begin{array}{c}0 \\
(\mathrm{NA})\end{array}$ & $\begin{array}{c}0 \\
(\mathrm{NA})\end{array}$ & $\begin{array}{l}-0.01 \\
(1.11)\end{array}$ \\
\hline $\begin{array}{l}\delta \\
(t-s t a t)\end{array}$ & $\begin{array}{c}0 \\
(\mathrm{NA})\end{array}$ & $\begin{array}{c}-0.03 \\
(-100.23)\end{array}$ & - & $\begin{array}{c}0.02 \\
(27.46)\end{array}$ & $\begin{array}{c}-0.03 \\
(-28.27)\end{array}$ & $\begin{array}{c}0 \\
(\mathrm{NA})\end{array}$ & $\begin{array}{c}0 \\
(\mathrm{NA})\end{array}$ & $\begin{array}{c}0 \\
(\mathrm{NA})\end{array}$ & $\begin{array}{c}0 \\
(\mathrm{NA})\end{array}$ & $\begin{array}{c}0 \\
(\mathrm{NA})\end{array}$ & $\begin{array}{c}0.01 \\
(8.88)\end{array}$ & $\begin{array}{c}0.001 \\
(19.68)\end{array}$ & $\begin{array}{l}-0.0001 \\
(-26.93)\end{array}$ & $\begin{array}{c}0 \\
(4.76)\end{array}$ \\
\hline $\begin{array}{l}L q \\
(t-s t a t)\end{array}$ & $\begin{array}{c}0 \\
(\mathrm{NA})\end{array}$ & $\begin{array}{c}0 \\
(\mathrm{NA})\end{array}$ & $\begin{array}{c}-158.9 \\
(-21.30)\end{array}$ & - & $\begin{array}{c}-25.64 \\
(-95.99)\end{array}$ & $\begin{array}{c}0.03 \\
(2.12)\end{array}$ & $\begin{array}{c}-120.56 \\
(-8.70)\end{array}$ & $\begin{array}{l}-228.42 \\
(-26.14)\end{array}$ & $\begin{array}{c}-0.03 \\
(-3.97)\end{array}$ & $\begin{array}{c}0.06 \\
(5.59)\end{array}$ & $\begin{array}{c}12.06 \\
(40.51)\end{array}$ & $\begin{array}{c}0 \\
(\mathrm{NA})\end{array}$ & $\begin{array}{c}0 \\
(\mathrm{NA})\end{array}$ & $\begin{array}{c}0 \\
(\mathrm{NA})\end{array}$ \\
\hline $\begin{array}{l}G g d p \\
(t-s t a t)\end{array}$ & $\begin{array}{c}0 \\
(\mathrm{NA})\end{array}$ & $\begin{array}{c}0 \\
(\mathrm{NA})\end{array}$ & $\begin{array}{c}0 \\
(\mathrm{NA})\end{array}$ & $\begin{array}{c}0 \\
(\mathrm{NA})\end{array}$ & $\begin{array}{c}-0.11 \\
(-101.86)\end{array}$ & $\begin{array}{l}0.001 \\
(8.88)\end{array}$ & - & $\begin{array}{c}0.68 \\
(14.23)\end{array}$ & $\begin{array}{c}-0.0001 \\
(-9.87)\end{array}$ & $\begin{array}{c}0.0001 \\
(4.04)\end{array}$ & $\begin{array}{c}0.04 \\
(22.98)\end{array}$ & $\begin{array}{l}0.0001 \\
(13.72)\end{array}$ & $\begin{array}{c}0.0001 \\
(14.83)\end{array}$ & $\begin{array}{c}0 \\
(\mathrm{NA})\end{array}$ \\
\hline $\begin{array}{l}D e f g d p \\
(t-s t a t)\end{array}$ & $\begin{array}{c}0 \\
(\mathrm{NA})\end{array}$ & $\begin{array}{c}0 \\
(\mathrm{NA})\end{array}$ & $\begin{array}{c}0 \\
(\mathrm{NA})\end{array}$ & $\begin{array}{c}0 \\
(\mathrm{NA})\end{array}$ & $\begin{array}{c}0 \\
(\mathrm{NA})\end{array}$ & $\begin{array}{c}-0.0001 \\
(-2.73)\end{array}$ & $\begin{array}{c}-0.01 \\
(-0.40)\end{array}$ & - & $\begin{array}{c}0.0001 \\
(10.66)\end{array}$ & $\begin{array}{c}0 \\
(\mathrm{NA})\end{array}$ & $\begin{array}{c}0.02 \\
(43.93)\end{array}$ & $\begin{array}{c}-0.0001 \\
(-3.60)\end{array}$ & $\begin{array}{l}-0.0001 \\
(-16.24)\end{array}$ & $\begin{array}{l}-0.0001 \\
(-33.40)\end{array}$ \\
\hline
\end{tabular}

a- The sample period is 1970Q1-2017Q4. $L I$ is the log of investment, $L K$ is the log of stock of capital, $\delta$ is the depreciation rate, $L q$ and $L w$ are the log of price of capital and real wage rate, respectively, $r^{*}$ is the 3 -month real corporate paper rate, Ggdp is the federal government expenditures on goods and services per GDP, Defgdp is the federal deficit per GDP, Debtgdp is the outstanding federal debt per GDP, Fdebtgdp is the federal foreign-financed debt per GDP, and $L G I$ is the log of the real federal government investment. The short-run dynamics of the regressions also includes dummy variables $N a$ fta $(=1$ for $1994: 01$ and on, $=0$, otherwise), Taxre form 86 ( $=1$ for 1986:04 and on, =0, otherwise), BushTcut ( $=1$ for 2003:03 and 2010:04, =0, otherwise), and USCRISIS (=1 for 2007:04 and 2009:03, =0, otherwise).

b- $\operatorname{LM}(1)$ and $\operatorname{LM}(2)$ are one and two-order Lagrangian Multiplier tests, respectively (Godfrey, 1978, 1988).

c- We cannot reject the null of the number of $\rho$ (the number of cointegration relationships) $=6$. 
Table A.2: Long-Run Test Results ${ }^{a}$

\begin{tabular}{|c|c|c|c|c|c|c|c|c|c|c|c|c|c|}
\hline \multicolumn{14}{|c|}{$\begin{array}{l}\text { The Model Specified by equation }(20) \\
\text { Tests of the Cointegration Rank }(\rho)\end{array}$} \\
\hline$H_{0}=\rho$ & $\mathbf{0}$ & 1 & 2 & 3 & 4 & 5 & 6 & 7 & 8 & 9 & \multicolumn{3}{|c|}{ Diagnostic tests ${ }^{b} p$-value } \\
\hline $\begin{array}{l}\text { Rank test } \\
\text { statistics }^{c}\end{array}$ & 469 & 363 & 290 & 226 & 173 & 123 & 82 & 49 & 19 & 4 & \multirow{2}{*}{\multicolumn{3}{|c|}{$\begin{array}{l}\text { Autocorrelation } \\
\operatorname{LM}(1): 0.00 \\
\operatorname{LM}(2): 0.102 \\
\text { ARCH } \\
\operatorname{LM}(1):(0.00) \\
\operatorname{LM}(2): 0.058 \\
\text { Normality: } 0.00 \\
\text { Lag length }=\mathbf{6}\end{array}$}} \\
\hline$p$-value & 0 & 0 & 0 & 0 & 0.01 & $0.08^{d}$ & 0.28 & 0.35 & 0.45 & 1 & & & \\
\hline \multicolumn{14}{|c|}{ Identified Long-Run Relationships for $\rho=5 . \chi^{2}(6)=3.33(0.77)$} \\
\hline Normalized & $I / K$ & $\delta$ & $L q$ & $L w$ & $r^{*}$ & $G g d p$ & Defgdp & Debtgdp & Fdebtgdp & $L G I$ & $\mathrm{~T}(' 91: 04)$ & $\mathrm{T}(' 08: 03)$ & Trend \\
\hline $\begin{array}{l}I / K \\
(t-s t a t)\end{array}$ & - & $\begin{array}{c}0 \\
(\mathrm{NA})\end{array}$ & $\begin{array}{c}0.14 \\
(9.55)\end{array}$ & $\begin{array}{l}-0.28 \\
(-3.36)\end{array}$ & $\begin{array}{l}-0.01 \\
(-5.58)\end{array}$ & $\begin{array}{c}3.5 \\
(2.98)\end{array}$ & $\begin{array}{c}2.47 \\
(2.01)\end{array}$ & $\begin{array}{l}-0.001 \\
(-1.85)\end{array}$ & $\begin{array}{l}-0.001 \\
(-4.83)\end{array}$ & $\begin{array}{c}-0.02 \\
(-0.68)\end{array}$ & $\begin{array}{c}0 \\
(\mathrm{NA})\end{array}$ & $\begin{array}{c}0 \\
(\mathrm{NA})\end{array}$ & $\begin{array}{c}0 \\
(\mathrm{NA})\end{array}$ \\
\hline $\begin{array}{l}\delta \\
(t-s t a t)\end{array}$ & $\begin{array}{c}0 \\
(\mathrm{NA})\end{array}$ & - & $\begin{array}{c}0.01 \\
(1.63)\end{array}$ & $\begin{array}{c}-0.31 \\
(-11.92)\end{array}$ & $\begin{array}{l}-0.004 \\
(-10.82)\end{array}$ & $\begin{array}{l}2.97 \\
(8.2)\end{array}$ & $\begin{array}{l}-0.93 \\
(-2.47)\end{array}$ & $\begin{array}{l}-0.001 \\
(-6.25)\end{array}$ & $\begin{array}{c}0 \\
(\mathrm{NA})\end{array}$ & $\begin{array}{c}-0.01 \\
(-0.72)\end{array}$ & $\begin{array}{c}0 \\
(\mathrm{NA})\end{array}$ & $\begin{array}{c}0 \\
(\mathrm{NA})\end{array}$ & $\begin{array}{c}0.0001 \\
(10.8)\end{array}$ \\
\hline $\begin{array}{l}L q \\
(t-s t a t)\end{array}$ & $\begin{array}{c}0 \\
(\mathrm{NA})\end{array}$ & $\begin{array}{c}0 \\
(\mathrm{NA})\end{array}$ & - & $\begin{array}{c}-4.49 \\
(-15.39)\end{array}$ & $\begin{array}{l}0.01 \\
(1.4)\end{array}$ & $\begin{array}{c}1.74 \\
(0.58)\end{array}$ & $\begin{array}{c}6.6 \\
(2.05)\end{array}$ & $\begin{array}{c}-0.01 \\
(-9.05)\end{array}$ & $\begin{array}{c}0.02 \\
(6.88)\end{array}$ & $\begin{array}{c}0 \\
(\mathrm{NA})\end{array}$ & $\begin{array}{c}0 \\
(\mathrm{NA})\end{array}$ & $\begin{array}{c}0 \\
(\mathrm{NA})\end{array}$ & $\begin{array}{c}0.02 \\
(30.12)\end{array}$ \\
\hline $\begin{array}{l}L q \\
(t-s t a t)\end{array}$ & $\begin{array}{c}0 \\
(\mathrm{NA})\end{array}$ & $\begin{array}{l}-367.79 \\
(-15.62)\end{array}$ & - & $\begin{array}{c}-26.05 \\
(-13.42)\end{array}$ & $\begin{array}{c}0 \\
(\mathrm{NA})\end{array}$ & $\begin{array}{l}-29.24 \\
(-1.26)\end{array}$ & $\begin{array}{c}0 \\
(\mathrm{NA})\end{array}$ & $\begin{array}{c}0 \\
(\mathrm{NA})\end{array}$ & $\begin{array}{c}0 \\
(\mathrm{NA})\end{array}$ & $\begin{array}{c}2.5 \\
(2.4)\end{array}$ & $\begin{array}{c}0 \\
(\mathrm{NA})\end{array}$ & $\begin{array}{c}-0.08 \\
(-5.47)\end{array}$ & $\begin{array}{l}0.04 \\
(6.2)\end{array}$ \\
\hline $\begin{array}{l}r^{*} \\
(t-s t a t)\end{array}$ & $\begin{array}{c}0 \\
(\mathrm{NA})\end{array}$ & $\begin{array}{c}0 \\
(\mathrm{NA}) \\
\end{array}$ & $\begin{array}{c}0 \\
(\mathrm{NA})\end{array}$ & $\begin{array}{c}0 \\
(\mathrm{NA})\end{array}$ & - & $\begin{array}{c}1203.01 \\
(13.55) \\
\end{array}$ & $\begin{array}{c}-1235.45 \\
(-10.95)\end{array}$ & $\begin{array}{c}0 \\
(\mathrm{NA})\end{array}$ & $\begin{array}{c}0 \\
(\mathrm{NA})\end{array}$ & $\begin{array}{c}-3.17 \\
(-1.70)\end{array}$ & $\begin{array}{c}-0.09 \\
(-6.50)\end{array}$ & $\begin{array}{c}0.25 \\
(10.38) \\
\end{array}$ & $\begin{array}{c}0 \\
(\mathrm{NA})\end{array}$ \\
\hline \multicolumn{14}{|c|}{ Fully Modified Least Square ${ }^{e}$} \\
\hline Normalized & $I / K$ & $\delta$ & $L q$ & $L w$ & $r^{*}$ & $G g d p$ & $D e f g d p$ & Debtgdp & Fdeptgdp & $L G I$ & T ('91:04) & $\mathrm{T}(' 08: 03)$ & Trend \\
\hline $\begin{array}{l}I / K \\
(t-s t a t)\end{array}$ & - & $\begin{array}{c}0.43 \\
(2.04) \\
\end{array}$ & $\begin{array}{c}-0.01 \\
(-1.96) \\
\end{array}$ & $\begin{array}{c}-0.04 \\
(-3.05)\end{array}$ & $\begin{array}{c}0.0003 \\
(3.26) \\
\end{array}$ & $\begin{array}{c}-0.15 \\
(-1.45) \\
\end{array}$ & $\begin{array}{c}-0.46 \\
(-6.70) \\
\end{array}$ & $\begin{array}{c}-0.0001 \\
(-1.83) \\
\end{array}$ & $\begin{array}{c}0.0003 \\
(2.2) \\
\end{array}$ & $\begin{array}{l}0.005 \\
(1.12) \\
\end{array}$ & $\begin{array}{l}-0.003 \\
(-3.16) \\
\end{array}$ & $\begin{array}{c}-0.01 \\
(-4.57) \\
\end{array}$ & $\begin{array}{l}0.001 \\
(7.93) \\
\end{array}$ \\
\hline
\end{tabular}

a- The sample period is 1970Q1-2017Q4. The variable $I / K$ is the investment per stock of capital. See the note of Table A.1 for other variable definitions. Note that we also allow the short-run dynamics of the system to be affected by the US financial crisis, NAFTA agreement, and tax reforms of 1986 and 2003.

b- $\operatorname{LM}(1)$ and $\operatorname{LM}(2)$ are one and two-order Lagrangian Multiplier tests, respectively (Godfrey, 1978, 1988).

c- Trace has been multiplied by the small sample correction factor $(N-k p) / N$, where $N$ is the number of observations, $k$ is the number of lag and $p$ is the number of endogenous variables (Cheung \& Lai, 1993).

$\mathrm{d}$-We cannot reject the null of $\rho$ (the number of cointegration relationships) $=5$.

e- The regression also includes constant, dummy variables for the US financial crisis, NAFTA agreement, and tax reforms. See the note of Table A.1. 
Table A.3: Error-Correction Model, Dependent Variable: $\Delta I / K$

\begin{tabular}{|c|c|c|c|}
\hline Variable & Coefficient & $t$-statistics & Hansen's stability $\mathrm{L}_{i}$ test at $5 \%$ critical value \\
\hline Constant & -0.003 & -3.18 & 0.54 \\
\hline$\Delta L q_{t-3}$ & 0.013 & 2.18 & 0.9 \\
\hline$\Delta L q_{t-4}$ & -0.021 & -2.3 & 0.84 \\
\hline$\Delta L q_{t-5}$ & 0.02 & 2.4 & 0.94 \\
\hline$\Delta D e f g d p_{t-6}$ & 0.141 & 3.5 & 0.58 \\
\hline$\Delta$ Debtgdp $p_{t-1}$ & -0.0003 & -3.45 & 0.94 \\
\hline$\Delta$ Debtgdp $p_{t-5}$ & 0.0003 & 3.47 & 0.96 \\
\hline$\Delta r_{t-4}^{*}$ & -0.0001 & -2.26 & 0.59 \\
\hline$\Delta r_{t-6}^{*}$ & -0.0001 & -1.9 & 0.74 \\
\hline$E C_{t-3}$ & -0.02 & -4.26 & 0.65 \\
\hline$E C_{t-1}^{2}$ & -0.02 & -4.21 & 0.69 \\
\hline USCRISIS & -0.002 & -4.75 & 1 \\
\hline \multirow{3}{*}{\multicolumn{3}{|c|}{$\begin{array}{l}\text { Hansen (1992)'s stability } \mathrm{L}_{i} \text { test on the vari- } \\
\text { ance }=0.37 \\
\text { Joint (coefficients and the error variance) } \\
\text { Hansen (1992)'s stability } \mathrm{L}_{c} \text { test }=1.54\end{array}$}} & $p$-value $=0.08$ \\
\hline & & & $p$-value $=0.90$ \\
\hline & & & \\
\hline \multicolumn{3}{|c|}{ Normality, Jarque-Bera $=0.78$} & $p$-value $=0.68$ \\
\hline
\end{tabular}

The sample period is 1970Q1-2017Q4. $\triangle$ means the first difference; USCRISIS and TAXREFORM are dummy variables to account for the US crisis of 2007 and the tax reform of President Bush, respectively. For the definition of other variables, see the note of Table A.1.

$\mathrm{EC}$ is the error correction term which is defined as

$E C_{t}=I / K-0.14 L q+0.28 L w+0.01 r^{*}-3.50 G g d p-2.47$ Defgdp +0.001 Debtgdp +0.001 Fdebtgdp $+0.02 L G I$

Specification Tests: $\bar{R}^{2}=0.43, \sigma=0.001, D W=2.06$, Godfrey $(6)=0.39$ (significance level $=0.88$ ), White $=80.60$ (significance level=0.28), $\operatorname{ARCH}(5)=11.08$ (significance level=0.05), and $\operatorname{RESET}(3)=1.99$ (significance level=0.12). Note that $\bar{R}^{2}$ and DW, respectively, denote the adjusted squared multiple correlation coefficient, the residual standard deviation and the Durbin Watson statistic. White is White (1980)'s general test for heteroscedasticity, ARCH is five-order Engle (1982)'s test, Godfrey is five-order Godfrey (1978)'s test, RESET is Ramsey (1969)'s misspecification test, Normality is Jarque \& Bera (1987)'s normality statistics, $\mathrm{L}_{i}$ is Hansen (1992)'s stability test for the nul hypothesis that the estimated coefficient or variance of the error term is constant and $\mathrm{L}_{c}$ is Hansen (1992)'s stability test for the null hypothesis that the estimated coefficients as well as the error variance are jointly constant. 